九州大学学術情報リポジトリ

Kyushu University Institutional Repository

\title{
Screening of Xylanase-Producing Rhizopus spp.
}

Veluz, Guilberto A.

Laboratory of Food Processing, Faculty of Agriculture, Kyushu University

Katoh, Tatsuo

Laboratory of Food Processing, Faculty of Agriculture, Kyushu University

Morita, Hiroshi

Laboratory of Food Processing, Faculty of Agriculture, Kyushu University

Fujio, Yusaku

Laboratory of Food Processing, Faculty of Agriculture, Kyushu University

https://doi.org/10.5109/24288

出版情報：九州大学大学院農学研究院紀要. 43 (3/4)，pp.419-423，1999-02. Kyushu University バージョン：

権利関係 : 


\title{
Screening of Xylanase-Producing Rhizopus spp.
}

\section{Guilberto A. Veluz, Tatsuo Katoh, Hiroshi Morita and Yusaku Fujio}

\author{
Laboratory of Food Processing, Faculty of Agricuiture \\ Kyushu University, Fukuoka 812-8581, Japan \\ (Received October 20, 1998 and accepted November 6, 1998)
}

\begin{abstract}
A total of 67 strains of Rhizopus spp. were screened on their capability to produce xylanase under solid state and liquid culture. The highest xylarase activity of 516 unit/mL. for liquid culture was exhibited by strain Rhizopus peka from the Philippines. For solid statc culture, the highest activity of 7802 unit/ml was achieved by Rhizopus sp. MKU 32 which originated from Thailand. Results showed that liquid culture was more suitable for xylanase production using Rhizopus strains from the Philippines.
\end{abstract}

\section{IN'TRODUCTION}

Investigation on new and different xylan-digesting microorganisms has increased through the years because of the importance of bio-converting waste xylan, which is abundant in agriculture and the farm-industry. Wong et al. (1988) has reported the application of xylanase (EC3.2.1.8, 1,4 $\beta$-D-xylanohydrolase) for bio-conversion processes, such as bio-pulping and food processing. In these aspects, several types of microbial xylanases were reported like bacterial xylanase from Bacillus sp. (Horikoshi and Atsukawa, 1973, Honda et al., 1985, Dey et al., 1991, Park et al., 1992), fungal xylanase from Aspergillus niger (John, et al., 1978, Frederick et al., 1984), yeast xylanases from Cryptococcus albidus (Biely et al., 1980, lefuji et al., 1996) and Trichosporon culaneum (Stuttgen and Sahm, 1982). Some of these xylanases were previously purified and characterized. Other xylanase producing microorganisms known to date are Aeromonus sp. (Ohkoshi, et al., 1985), Humicola lanuginisa (Kitpreechavanich et al., 1989), Sporotrichum cellulophilum (Lerrwerawat and Hinoshita, 1989), Aureobasidium pullulans (Li, et al., 1993), Trichoderma viride (Hashimoto, et al., 1971), Talaromyces byssochlamydoides (Yoshioka, et al., 1981), Clostridum (Wong, et al., 1988) and Streptomyces (Wong, et al., 1988).

Since there has been no report on Rhizopus as a source of xylanase, this paper deals with the screening of xylanase-producing Rhizopus strains.

\section{MATERIALS AND METHODS}

\section{Microorganisms}

A total of 67 Rhizopus strains were used in the study. Forty six strains came from the laboratory stock cultures including TISTR type culture, MKU collection, UQM collection and new isolates. The other 21 strains came from the MNH-MCC, UPLB and IFST, UPLB culture collection in the Philippines. These strains were stocked on a PDA slant agar. 


\section{Liquid medium}

The liquid medium composition (Morita and Fujio, 1997) was $10 \mathrm{~g}$ liquefied cassava starch, $4 \mathrm{~g}$ ammonium acetate, $1 \mathrm{~g}$ dipotassium hydrogen phosphate, $0.5 \mathrm{~g}$ magnesium sulfate heptahydrate, $0.01 \mathrm{~g}$ iron sulfate heptahydrate, $0.03 \mathrm{~g}$ zinc sulfate heptahydrate, $0.21 \mathrm{~g}$ calcium chloride, $3.3 \mathrm{~g}$ citric acid and $1.0 \mathrm{~L}$ deionized water. The $\mathrm{pH}$ was adjusted to 6.0 and $100 \mathrm{~mL}$ of the medium was distributed in a $500 \mathrm{~mL}$, shaking flask with a cotton plug. The shaking flask was autoclaved at $121^{\circ} \mathrm{C}$ for $20 \mathrm{~min}$.

\section{Solid medium}

The solid medium was composed of $20 \mathrm{~g}$ wheat bran, $2 \mathrm{~g}$ cassava starch and $20 \mathrm{~mL}$ tap water which was distributed in a $500 \mathrm{mI}$. Frlenmeyer flask with a cotton plug. After mixing well, the medium was autoclaved at $121^{\circ} \mathrm{C}$ for $20 \mathrm{~min}$.

\section{Inoculum preparation and inoculation}

Rhizopus strain from stock culture was transferred in a fresh PDA slant and pre-cultured at $30^{\circ} \mathrm{C}$ for one week. Spore and mycelium suspension was prepared by adding $13 \mathrm{~mL}$ sterile water to pre-cultured Rhizopus and scratching the agar surface using platinum loop. A $2 \mathrm{~mL}$ spore suspension per a flask was inoculated for both solid and liquid media.

\section{Culture condition}

Liquid cultivation was carried out at $30^{\circ} \mathrm{C}$ for 2 days on a rotary shaker while soljd medium was incubated at $30^{\circ} \mathrm{C}$ for 7 days.

\section{Preparation of enzyme solution}

After incubation, the culture broth from liquid culture medium was filtered using filter paper (Toyo No. 7) and the filtrate was used as crude enzyme solution. For solid culture, $200 \mathrm{~mL}$ deionized water was added in the cultured flask and mixed well. The mixture was placed in a cold room at $4^{\circ} \mathrm{C}$ for $20 \mathrm{~h}$ and then centrifuged at $7,012 \times$ at $4^{\circ} \mathrm{C}$ for $20 \mathrm{~min}$. The supernatant liquid was used as crude xylanase solution.

\section{Determination of xylanase activity}

Xylanase activity was determined using $1 \%$ xylan (from Oat-spelts, Nacalai Tesque, Kyoto, Japan) as a substrate suspended in a $0.1 \mathrm{M}$ sodium acetate buffer ( $\mathrm{pH} 4.5$ ). A $0.5 \mathrm{~mL}$ xylanase solution was added in a $0.5 \mathrm{~mL}$ substrate suspension and incubated at $40^{\circ} \mathrm{C}$ for $30 \mathrm{~min}$. The amount of reducing sugar liberated was determined by the DNS method (Miller, 1959) and measured the absorbance at $547 \mathrm{~nm}$ using D-xylose as the standard. One unit of xylanase activity was defined as the amount of enzyme that produces $1.0 \mu \mathrm{mol}$ of xylose per min under the given conditions.

\section{RESULTS AND DISCUSSION}

\section{Xylanase production}

Table 1 shows the results of the screening of 64 laboratory stock of Rhizopus strains on xylanase production under liquid and solid culture. For liquid culture, a maximum 
activity of 310 units was achieved by Rhizopus sp. MKU 10. Sixteen strains did not produce any xylanase under this condition. In the case of solid culture, maximum activity was achieved by Rhizopus sp. MKU 32 units and only one strain, MKU 24, did not exhibit xylanase production.

Higher xylanase production was also noted in solid culture. Thirty two strains resulted in more than 100 units, compared to 18 strains for liquid culture. From the results, it can be said that solid culture is more suitable for higher xylanase production.

Table 2 shows the result for 21 Rhizopus strains originating from the Philippines. Maximum xylanase activity was exhibited by Rhizopus peka (P8) at 516 units and Rhizopus stolonifer (P4) at 436 units for liquid and solid culture, respectively. All Rhizopus strains tested, showed capability to produce xylanase under liquid medium. Poor xylanase production, between 0-100 units, was observed in 13 strains under solid medium. In contrast to laboratory stock cultures (Table 1), liquid culture is said to be more suitable for xylanase production for Rhizopus strains from the Philippines. Except for Rhizopus stolonifer (P4), all strains have higher xylanase activity under liquid culture. Some of the strains from Japan showing high xylanase activity were further tested and are still under study for purification and characterization of the enzyme.

Table 1. Xylanase production by liquid culture (LC) and solid culture (SC) of hizizopus sp. and some type culture from laboratory stock culture.

\begin{tabular}{|c|c|c|c|c|c|}
\hline \multicolumn{6}{|c|}{ Xylanase activity (unit) } \\
\hline Code No. & $\mathrm{LC}$ & $\mathrm{SC}$ & Code No. & LC & Sc \\
\hline MKU 4 & 248 & 312 & IFO 4697 & 88 & 312 \\
\hline MKU 7 & 210 & 148 & IFO 5441 & 38 & 100 \\
\hline MKU 8 & 300 & 522 & IFO 5442 & 86 & 260 \\
\hline MKU 10 & 310 & 110 & LQM $186 \mathrm{~F}$ & 60 & 200 \\
\hline MKL 11 & 120 & 452 & F60 & 272 & 200 \\
\hline MKL 12 & 236 & 394 & $F 61$ & 0 & 330 \\
\hline MKL 17 & 210 & 8 & F62 & 100 & 236 \\
\hline MKU 18 & 248 & 8 & $F 64$ & 0 & 110 \\
\hline MKU 21 & 100 & 110 & $\mathrm{~F} 67$ & 0 & 8 \\
\hline MKU 24 & 200 & 0 & $\mathrm{~F} 68$ & 148 & 336 \\
\hline MKU 32 & 184 & 702 & F89 & 60 & 468 \\
\hline MKU 38 & 20 & 300 & F94 & 0 & 20 \\
\hline MKU 40 & 126 & 60 & F98 & 122 & 260 \\
\hline MKU 42 & 10 & 312 & 66 & 60 & 110 \\
\hline T3001 & 50 & 136 & (17 7 & 184 & 88 \\
\hline T3052 & 0 & 386 & G82 & 100 & 134 \\
\hline Т3079 & 0 & 70 & LKN & 50 & 86 \\
\hline T3155 & 0 & 50 & Al1 & 48 & 574 \\
\hline T3189 & 36 & 236 & LM & 0 & 74 \\
\hline T3165 & 0 & 386 & WJ & 0 & 312 \\
\hline T3211 & 0 & 8 & ON & 0 & 136 \\
\hline $\mathrm{T} 3241$ & 0 & 74 & Rh3 & 0 & 110 \\
\hline T3247 & 0 & 248 & & & \\
\hline Т3324 & 0 & 36 & & & \\
\hline
\end{tabular}

MKU, T (TISTR) IFO and QUM were from culture collection. Others were isolates. 
Table 2. Xylanase production by liquid eulture (LC) and solid culture (SC) of Rhizopas from the Philippines (MNH-MCC)

\begin{tabular}{|c|c|c|c|c|c|}
\hline \multicolumn{2}{|l|}{. } & \multicolumn{4}{|c|}{ Xylanase activity (unit) } \\
\hline Rhizoptus strain & JC & $\mathrm{SO}$ & Rhtzopus strain & $\mathrm{LC}$ & SC \\
\hline Fh, oryzae, $\mathrm{P}^{3} 1$ & 372 & 50 & Rh. oligospons, $\mathrm{P} 12$ & 316 & 232 \\
\hline Rh. oligosporus, $\mathrm{P}_{2}$ & 432 & 128 & Rh. oligosporus, P13 & 308 & 32 \\
\hline Rh oryzae, $\mathrm{P} 3$ & 508 & 96 & Rh. oligosporus, $\mathrm{P} 14$ & 386 & 206 \\
\hline Th. stolonifer, $\mathrm{P} 4$ & 134 & 436 & $R h . s p$, P15 & 250 & 68 \\
\hline Rh. cohnit, $\mathrm{P} 5$ & 448 & 144 & Kh. javanicus, $\mathrm{P} 16$ & 364 & 12 \\
\hline Rh. tamarie $\mathrm{l}^{2} 6$ & 436 & 138 & Kh. oryzae, $\mathrm{P} 17$ & 306 & 0 \\
\hline Rh. arrhizus, $\mathrm{P} 7$ & 440 & 364 & Rh. oligosporus, $\mathrm{P} 18$ & 202 & 0 \\
\hline Rh. peka, $\mathrm{P} 8$ & 516 & 0 & Rh. arrhizus, $\mathrm{P} 20$ & 280 & 0 \\
\hline Rh. oligosporus, $\mathrm{P9}$ & 268 & 0 & Rh. oligosporus, P21 & 252 & 0 \\
\hline Rh. oligosporus, $\mathrm{P} 10$ & 220 & 188 & Rh. sp., $\mathrm{P} 22$ & 372 & 0 \\
\hline Rh oligosporus, $\mathrm{P} 11$ & 188 & 50 & & & \\
\hline
\end{tabular}

Rh. (Rhizopus).

\section{Xylanase production and other hydrolases}

In previous studies by Elegado and Fujio (1993) on the production of soluble starch digestive glucoamylase (GA) and raw starch digestive glucoamylase (GARS), it was reported that Rhizopus strains Rh3, IFO 5441 (from Table 1) are good GA and GARS producers. Similarly, these strains produced xylanase activity but were reported to produce high GA. Other strains like F60, F61, F62, F67, F68, F89, F98, IFO 5442 and G8 were reported to produce less than 100 units of GA, although most of these strains have more than 100 units of xylanase activity.

\section{ACKNOWLEDGMENTS}

The authors wish to thank the ICBiotech, Japanese Government, UNESCO and ICRO for their support on this work.

\section{REFERENCES}

Biely, P., M. Vrsanska and Z. Kratky 1980 Xylan-degrading enzymes of the yeast Cryptoroccus albidus. Eur. J. Biochem., 108: 313-321

Trey, D., J. Hinge, A. Shendye and M. Rao 1991 Purification and properties of extracellular endoxylanases from alkalophilic thermophilic Bacillus sp.. Can. J. Microbiol., 38: 436-442

Elegado, F. B. and Y. Fujio 1993 Sclection of raw-starch digestive glucoamylase proucing Rhizopus strain. J. Gen. Appl. Microbiol., 39: 541-546

Frederick, M. M., C. H. Kiang, J. R. Frederick and P. J. Reilly 1984 pureification and characerization of endo-xylanase from Aspergillus niger. Biotech. Bioeng., 27: 525-532

Hashimoto. S., T. Muramatsu and M. Fundsu 1971 Studies on xylanase from Tricoderma viride. Agric. Biol. Chen., 35: 501-508

Honda, H., T. Kudo, Y. Ikura and K. Horikoshi 1985 Two types of xylanase of alkalophilic Bacillus sp.. No. C-125. Can. J. Microbiol., 31: 538-542

Horikoshi, K. and Y. Atsukawa 1973 Xylanae produced by alkalophilic Bacillus No. C-52. Agric. Biol. 
Chem., 37: 2097-2103

Iefuji, H., M. Chino, M. Kato and Y. limura 1996 Acid xylanase from yeast Cryptococcus sp. S-2. Biosci. Biotech. Biochem., 60: 1331-1338

John, M., B. Sctmidt and J. Schmidt 1978 Purification and some propertics of five endo-1,4- $\beta$ -D-xylanases and a $\beta-$ I)-xylosidase produced by a strain of Aspergillus niger, Can. J. Biochern., 57 : 125-134

Kitpreechavanich, V., M. Hayashi and S. Nagai 1984 purification and properties of endo-1,4- $\beta$-xylanase from Humicola lanuginisa. Annual Reports of ICBiotech, 7: 407

Lerrwrawat, Y. and S. Kinoshita 1989 Purification of xylanase from culture filtrale of Sporotricum cellulophilum. Annual Reports of ICBiotcch, 12: 417-425

Li, X. C., 7. Q. Zhang, J. F. D. Dean, K. F. I. Eriksson and L. Ljungdahl 1993 Purification and characterization of a new xylan (APX-I) from the fungus Aureobasidium pullulans Y-2311-1. Appl. Environ. Microbiol, , 59: $3212-3218$

Miller, G. L. 1959 Use of dinitrosalicylic acid reagent for determination of reducing sugar. Anal. Chem., 31: $426-428$

Morita, H. and Y. Fujio 1997 High specific activity of raw-starch digesting glucoamylase producing Rhizopus sp. A-11 in liquid culture. Starch/Stärke, 49: 293-296

Ohkoshi, A., Y. Kudo, T. Mase and K. Horikoshi 1985 Purification of three types of xylanase from an alklophilic Aeromonas sp.. Agric. Biol. Chem., 49: 3037-3038

Park, Y. S., D. Y. Yum, D. H. Bai and J. H. Yu 1992 Xylantase from alkalophilic Bacillus sp.. YC-335. Biosci. Biotech. Biochem., 56: 1355-1356

Stuttgen, E. and H. Sahm 1982 Purification and properties of endo-1,4- $\beta$-xylanlase from Trichosporon cutaneum. Eur. J. Appl. Microbiol., 15: 93-99

Wong, K. K. Y., L. U. L. Yan and J. N. Saddler 1988 Muitiplicity of $\beta$-1,4-xylanase in microorganisms: Functions and applications. Microbiol. Reviews, 52: 305-317

Yoshioka, H., N. Nagato, S. Chavanich, N. Nilubol and S. Hayashida 1981 Purification and properties of thermostable xylanase from Talaromyces byssochlamydoides YH-50. Agric. Biol Chem., 45 : $2425-2432$ 